\title{
O novom kartografskom rječniku
}

\author{
Miljenko Lapaine ${ }^{\circledR}$ \\ Geodetski fakultet Sveučilišta u Zagrebu \\ miljenko.lapaine@geof.unizg.hr \\ Nedjeljko Frančula \\ Geodetski fakultet Sveučilišta u Zagrebu \\ nfrancul@geof.hr \\ Ivo-Pavao Jazbec \\ Zagreb \\ ipjazbec@gmail.com
}

SAŽETAK: Godine 2020. objavljen je Kartografski rječnik u izdanju Hrvatskoga kartografskog društva i Naklade Dominović. Od objavljivanja prvoga i jedinoga Višejezičnoga kartografskoga rječnika u Hrvatskoj prošlo je više od 40 godina. U tom razdoblju mnogo toga novoga dogodilo se u svijetu, što su autori pokušali obuhvatiti novim rječnikom. U ovom radu opisat ćemo probleme s kojima smo se susreli u radu na pripremi toga rječnika.

Ključne riječi: kartografija; karta; rječnik

\section{Uvod}

Kartografija je disciplina koja se bavi zasnivanjem, izradom, promicanjem i proučavanjem karata. Prema službenoj podjeli znanosti u Hrvatskoj, kartografija je grana geodezije, pa se prema tome ubraja među tehničke znanosti. Međutim, opće je poznato da su karte svuda oko nas, pa je kartografija dobrim dijelom sastavni dio geografije, geologije, pomorstva, šumarstva, agronomije, povijesti, arhitekture, pedagogije i mnogih drugih područja koja se koriste kartama i geoinformacijama.

Kartografija je u posljednjih 40-ak godina doživjela goleme promjene. Sve veće mogućnosti interaktivnosti na webu, zamjena papirnatih karata multimedijskima i elektroničkima, sve češći zahtjevi za trodimenzionalnim modelima krajolika zbog različitih analiza, simulacija i vizualizacija, globalni kartografski servisi i druge inovacije obuhvaćene su našim Kartografskim rječnikom (Frančula i dr. 2020). Svaki je naziv obrađen studiozno, a definiran je razumljivo i jasno.

(D) https://orcid.org/0000-0002-9463-2329 [Miljenko Lapaine]

(1) https://orcid.org/0000-0002-0198-9637 [Nedjeljko Frančula] 
To je strukovni rječnik koji sadržava nazive iz kartografije i njoj srodnih područja. Rječnik sadržava 2500 naziva koji su poredani po abecedi. Kada je naziv višerječan, navodi ga se pod nosećom imenicom.

Uz svaki naziv ide njegova definicija koja je redovito vrlo sažeta i u jednoj rečenici. Često se za objašnjenje daje uputa s vidi na srodne nazive. Kratku i sažetu definiciju obično slijedi napomena, koja je ponekad i nešto opsežnija, kako bi čitatelj, ako želi, mogao dobiti više informacija.

Sve su definicije na hrvatskom jeziku. Međutim, kartografija ne poznaje granice, pa su stoga za većinu naziva dani sinonimi na engleskom, francuskom i njemačkom jeziku. Posebno ističemo kazala na kraju rječnika, koja olakšavaju pronalaženje naziva na tim jezicima s uputama na odgovarajući naziv na hrvatskom jeziku.

\section{Prethodna iskustva}

U izdanju Geodetskoga fakulteta Sveučilišta u Zagrebu objavljen je 1977. Višejezični kartografski rječnik koji su sastavili nastavnici Zavoda za kartografiju Geodetskoga fakulteta Branko Borčić, Ivan Kreiziger, Paško Lovrić i Nedjeljko Frančula (Borčić i dr. 1977). Osnova za izradu rječnika bio je Multilingual Dictionary of Technical Terms in Cartography što ga je 1973. objavilo Međunarodno kartografsko društvo (International Cartographic Association - ICA). Taj rječnik ICA-e sadržava oko 1200 naziva. Definicije za svaki naziv dane su na engleskom, francuskom, njemačkom, ruskom i španjolskom, a samo nazivi bez definicija na još devet jezika. Rječnik je izradilo Povjerenstvo II (Definicije, klasifikacija i normizacija kartografskih naziva) ICA-e nakon devetogodišnjega rada.

Nastavnici Zavoda za kartografiju Geodetskoga fakulteta stupili su još 1972. u vezu s predsjednikom Povjerenstva II E. Meynenom i tajnikom Povjerenstva J. Neumannom i dobili na uvid jednu kopiju još neobjavljenoga rječnika. Ocijenili su da je taj rječnik, zbog načina kako je zamišljen i ostvaren, prvi korak $\mathrm{k}$ standardizaciji kartografske terminologije i odlučili izraditi hrvatski kartografski rječnik. Odlučili su, nadalje, da se u izradi našega rječnika što je moguće više oslone na rječnik ICA-e. Definicije u rječniku ICA-e izradile su nacionalne radne grupe. Analiza rječnika koju su izvršili pokazala je da postoje velike razlike u definicijama na pojedinim jezicima pa prevođenje definicija ni iz jednoga od tih jezika ne bi dalo potpuno zadovoljavajući rezultat, te da je bolje izraditi vlastite definicije.

$\mathrm{Na}$ osnovi analize definicija rječnika ICA-e, nastavnici Zavoda za kartografiju sastavili su kritičke primjedbe i dostavili ih Povjerenstvu II i predložili da u drugo izdanje rječnika ICA-e koje se počelo pripremati uđu i nazivi na hrvatskom jeziku. Primjedbe i sugestije nastavnika Zavoda za kartografiju naišle su na puno priznanje 
članova Povjerenstva II, pa su pozvani da u to Povjerenstvo delegiraju jednoga dopisnoga člana. Na prijedlog Zavoda za kartografiju u Povjerenstvo je izabran Branko Borčić. Prisustvovao je zasjedanju Povjerenstva II za vrijeme održavanja Četvrte međunarodne kartografske konferencije u Moskvi u kolovozu 1976. kada je jednoglasno prihvaćen prijedlog da se u drugo izdanje rječnika ICA-e unesu i nazivi na hrvatskom jeziku.

Drugo izdanje rječnika ICA-e objavljeno je 1997. pod naslovom Enzyklopädisches Wörterbuch Kartographie in 25 Sprachen (ISBN 3-598-10764-1). To izdanje sadržava definicije na već spomenutih pet jezika, a broj jezika na kojima su dane istovrijednice bez definicija povećan je s devet na dvadeset. Sa zadovoljstvom ističemo da je jedan od tih jezika i hrvatski.

Od objave Višejezičnoga kartografskoga rječnika prošlo je 40 godina i u tom je razdoblju kartografija doživjela goleme promjene. U prošlosti je postojala jasna razlika između autora i korisnika karata. Danas, međutim, posebno sa sve većim mogućnostima interaktivnosti na webu, tzv. demokratizacija kartografije ohrabruje sve veći broj ljudi da u punoj mjeri iskoriste svoje kartografske potencijale. To je posebno važno jer karte imaju temeljnu i prijeko potrebnu ulogu kao jedna od osnova naše civilizacije. Većina ljudskih djelatnosti vezanih uz prostor teško je ostvariva bez prikladnih kartografskih prikaza. Nabrojimo samo neke: prostorno planiranje, evidencija vlasništva nad zemljištem, vremenska prognoza, izgradnja prometnica, hitne službe, upravljanje šumama, iskorištavanje mineralnih sirovina, navigacija.

U proteklih nekoliko desetljeća tehnologija izrade karata iz temelja se promijenila. Papirnate karte izrađuju se danas isključivo digitalnom tehnologijom. Međutim, sve ih više zamjenjuju multimedijske ili elektroničke karte. To su karte povezane s tekstom, grafikonima, fotografijama, slikama, satelitskim ili aerosnimkama, drugim kartama, zvukom ili pokretnim slikama u multimediju radi pružanja dodatne razine informacija i potpunijega pogleda na stvarnost.

Velika prednost multimedijske karte u odnosu na otisnutu je brzina pretraživanja, mijenjanje mjerila, prebacivanje s jednoga dijela Zemljine sfere na drugi i sl. Osim toga, nismo ograničeni danim formatima već isječak koji nas zanima biramo sami. Sve mjerene veličine oslobođene su utjecaja deformacija projekcije, drugim riječima imamo pred sobom virtualni globus.

U današnje doba sve su češći zahtjevi za trodimenzionalnim modelima krajolika za različite analize, simulacije i vizualizacije. Virtualni globusi, kakav je npr. Google Earth, omogućuju prikaz krajolika gotovo cijeloga svijeta u tri dimenzije s mogućnošću mijenjanja kuta pod kojim taj krajolik promatramo. Velik je napredak napravio Google u posljednje vrijeme u 3D prikazu zgrada mnogih naselja u svijetu. 
Globalni kartografski servisi, kao što je Google Maps, pružaju neslućene mogućnosti primjene. Google Maps je prvenstveno namijenjen snalaženju u prostoru i kretanju od jedne točke do druge automobilom, javnim prijevozom, pješice, biciklom ili zrakoplovom. Za kretanje automobilom od jedne točke do druge aplikacija nacrta jednu ili više ruta, za svaku naznači duljinu u kilometrima i potrebno vrijeme. Slične usluge nude i drugi mrežni servisi, ali ono što Google Maps, uz još nekoliko mrežnih servisa, čini jedinstvenim jesu podatci o prometu u stvarnom vremenu. Četirima bojama (zelenom, žutom, crvenom i tamnocrvenom) označene su brzine prometa. Zelena znači normalnu brzinu prometa, žuta sporije prometne uvjete, crvena zagušenja i tamnocrvena upućuje na gotovo zaustavljen promet. Podatke o prometu Google dobiva automatski iz automobila preko pametnih telefona s ugrađenim GPS-om. Računajući brzinu kojom se korisnici kreću cestom Google generira kartu prometa u realnom vremenu.

Zbog svih navedenih promjena koje su se dogodile u kartografiji u posljednjih 40 godina smatrali smo potrebnim izraditi novi kartografski rječnik. Iz Višejezičnoga kartografskoga rječnika preuzeli smo mnoge nazive, a izostavili neke zastarjele. Dodali smo velik broj novih naziva, posebno iz područja digitalne kartografije, kartografskih projekcija, tematske kartografije i infrastrukture prostornih podataka.

Prije Kartografskoga rječnika (Slika 1.) o kojem je u ovom članku riječ objavljen je Geodetsko-geoinformatički rječnik (Frančula, Lapaine 2008). Naime, sve šira primjena geodezije i geoinformatike u raznim oblicima ljudske djelatnosti, kao i utjecaj općega razvoja znanosti i tehnike na geodeziju i geoinformatiku, znatno su proširili stručni vokabular kojim se danas služimo. Već se duže vrijeme osjećao u hrvatskoj geodetsko-geoinformatičkoj djelatnosti, i to u znanstvenom, nastavnom i stručnom radu nedostatak rječnika u kojem bi bilo zabilježeno nazivlje kakvo se danas upotrebljava. Osim toga, 1980. godine objavljen je Višejezični geodetski rečnik u izdanju Saveza geodetskih inženjera i geometara Jugoslavije (Stefanović 1980). Taj nas rječnik, međutim, ni u terminološkom, ni u jezičnom pogledu nije mogao zadovoljiti.

Stoga je 1995. godine Državnoj geodetskoj upravi predložen projekt izrade Geodetskoga rječnika koji je trebao biti pilot-projekt u kojem bi se utvrdili i istražili problemi koji se susreću pri sređivanju jezične građe, kako bismo jednoga dana mogli pokrenuti mnogo opsežniji projekt - izradu višesveščanoga i višejezičnoga geodetskoga rječnika. Rad na rječniku započet je 1996. i predviđalo se da će trajati tri godine. Rad se, međutim, odužio i rukopis je predan Državnoj geodetskoj upravi tek 2003. godine. Voditelj projekta bio je prof. dr. sc. Nedjeljko Frančula, glavni suradnik prof. dr. sc. Miljenko Lapaine, a u izradi rječnika surađivali su mnogi nastavnici i suradnici Geodetskoga fakulteta te određeni broj suradnika izvan toga fakulteta. 


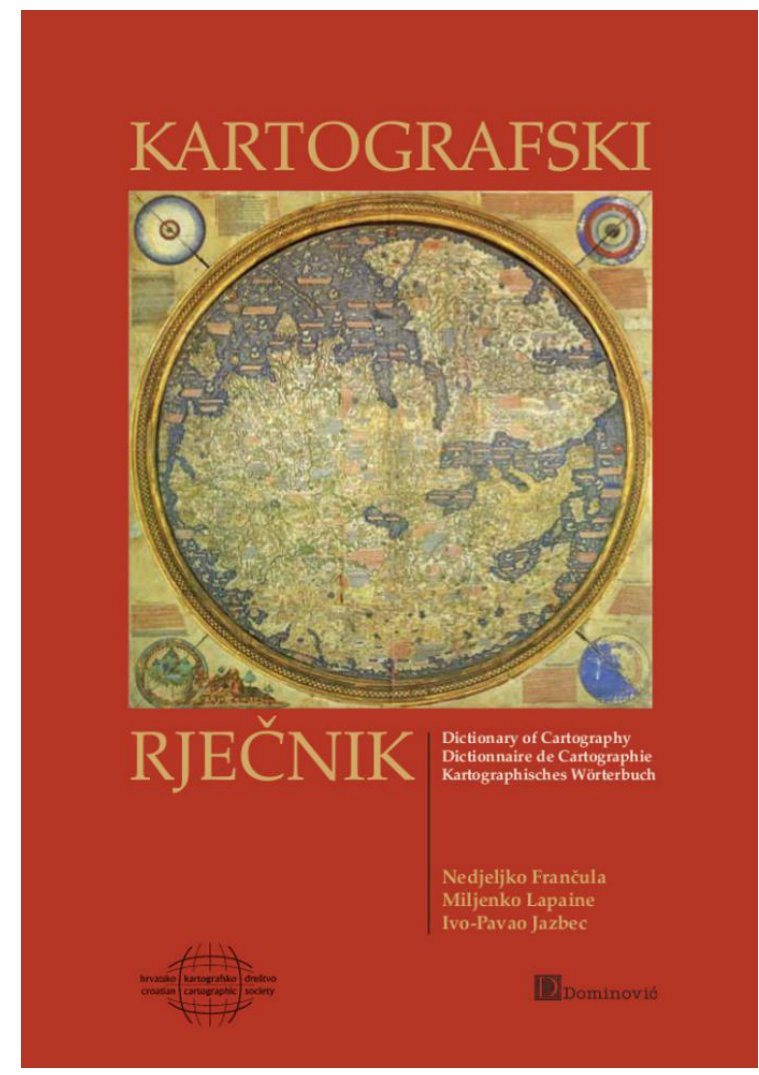

Slika 1. Naslovnica novoga kartografskoga rječnika

Bez obzira na to što je rukopis Geodetskog rječnika predan Državnoj geodetskoj upravi 2003. godine, nastavili smo s radom na stručnoj terminologiji. Sasvim je jasno da takvu radu zapravo nikad nema i neće biti kraja. Potvrda tome je sveopći razvoj tehnike, pa tako i geodezije. Sve veća primjena novih tehnologija dovela je do promjene sadržaja i naziva studija na Geodetskom fakultetu. Više se ne studira geodezija, nego geodezija i geoinformatika. U tom je smislu promijenjen i prvotni naslov rukopisa u Geodetsko-geoinformatički rječnik, a njegov je sadržaj dopunjen na odgovarajući način.

U Geodetsko-geoinformatičkom rječniku obrađeni su nazivi iz ovih područja: fizika s optikom, fotogrametrija i daljinska istraživanja, geodezija, geoinformatika, GIS (geoinformacijski sustavi), informatika, inženjerska geodezija, kartografija, katastar i zemljišna knjiga, matematička obrada geodetskih podataka, matematika, metrologija, mjerni instrumenti, pomorstvo, praktična geodezija, satelitska i fizikalna geodezija, statistika. Ukupno je obrađeno oko 4200 naziva. Rječnik je objavljen 2008., što znači da je rad na njemu trajao 12 godina. 
Izgradnja hrvatskoga strukovnoga nazivlja - 1. krug bio je projekt Hrvatsko strukovno nazivlje - projekt koordinacije (akronim STRUNA) koji se 2008. izvodio u Institutu za hrvatski jezik i jezikoslovlje. Cilj toga projekta bio je uspostaviti sustav koordinacije terminoloških djelatnosti u svim strukama u Hrvatskoj.

Izgradnja hrvatskoga strukovnog nazivlja - 2. krug sastojao se od tri projekta što ih je financirala Nacionalna zaklada za znanost, visoko školstvo i tehnologijski razvoj Republike Hrvatske, a koji su se izvodili u 2009. godini. Jedan od triju navedenih projekata bio je Kartografsko-geoinformatički rječnik, 1. faza (http://www.kartografija.hr/nzz/), kojem je voditelj bio Miljenko Lapaine. Rad na projektu završio je početkom 2010. godine, a rezultati su dostupni na internetskoj adresi http://struna. ihjj.hr/. U objavljenoj natječajnoj dokumentaciji piše: »Ti bi se projekti trebali ostvarivati interdisciplinarnom suradnjom jezikoslovaca i stručnjaka za pojedina područja, odnosno ustanova koje se takvim zadatcima bave. Naziv ima prednost ako odgovara pojmu kojemu je pridružen i odražava svoje mjesto u pojmovnome sustavu, a o tome može odlučiti predmetni stručnjak«. Iako je bilo predviđeno da stručnjaci za kartografiju i za jezikoslovlje surađuju i na kraju sporazumno objave rezultat rada, to se nažalost nije ostvarilo. Zadnju riječ imali su jezikoslovci pa je dio toga rječnika neupotrebljiv. Tako bi se npr. topografska karta trebala zvati topografski zemljovid i biti karta s informacijama o mjesnim prilikama prikazana područja s dopunjenim opisom karte is uvjetom njihove prikazbe sjednakom važnošću. Sasvim je jasno da takva nerazumljiva definicija ničemu ne služi. Osim toga, STRUNA nije dozvoljavala kratice kao zasebne jedinice rječnika premda suvremenu komunikaciju obilježava nastojanje da se u što kraćem vremenu i na što manjem prostoru donese što više obavijesti, o čemu npr. svjedoči Rječnik kratica S. Babića i M. Žic Fuchs objavljen 2007. godine. Taj je nedostatak otklonjen u ovom rječniku koji sadržava velik broj kratica.

\section{Problemi i njihovo rješavanje}

\subsection{Vrsta rječnika}

Rječnik je leksikografsko djelo koje sadržava popis riječi i izraza jednoga ili više jezika izabranih, raspoređenih i objašnjenih po nekom načelu te poredanih abecednim ili nekim drugim redoslijedom. U osnovi se razlikuju jezični rječnici i predmetni rječnici kao što su enciklopedija i leksikon.

Jezični se rječnik prvotno bavi jezikom, odnosno leksičkim jedinicama jezika i svim njihovim jezičnim osobinama. Novi Kartografski rječnik nije jezični rječnik jer se prvenstveno ne bavi jezikom.

Enciklopedija je opsežno djelo u kojem se, abecednim ili drugim metodičkim slijedom, sustavno obrađuju činjenice i spoznaje o sveukupnom ljudskom znanju. 
Opće enciklopedije obrađuju sva područja znanja, a specijalne enciklopedije samo znanja određenoga područja (npr. vojna, pomorska, književna itd.). Novi Kartografski rječnik nije enciklopedija jer ne obrađuje detaljno sveukupno znanje o kartografiji.

Leksikon je leksikografsko djelo ili predmetni rječnik koji daje pregled ukupnoga, općega znanja (opći leksikon) ili pregled znanja neke struke (strukovni leksikon). Natuknice se u leksikonu nižu abecednim ili metodičkim redoslijedom te sažeto obrađuju u velikom broju kratkih članaka koji prikazuju i tumače pojmove, znamenite osobe, vlastita i geografska imena, povijesna zbivanja, znanstveno i stručno nazivlje, tuđice ili zbirku riječi nekoga jezika. Novi Kartografski rječnik nije ni leksikon jer npr. ne sadrži znamenite osobe, vlastita i geografska imena ili povijesna zbivanja.

Postoje i druge podjele rječnika kao što su primjerice: rječnici za odrasle i rječnici za djecu te rječnici za strance i rječnici za izvorne govornike. Novi Kartografski rječnik nije namijenjen djeci, nego odraslima, među koje svakako ubrajamo i studente. Taj je rječnik namijenjen izvornim govornicima hrvatskoga jezika, ali se njime mogu koristiti i stranci budući da se na kraju rječnika nalaze abecedna kazala s nazivima na engleskom, francuskom i njemačkom jeziku uz odgovarajuće nazive na hrvatskom.

Konačno, rječnici mogu biti preskriptivni (koji propisuju) i deskriptivni (koji opisuju). Deskriptivni rječnici prikupljaju rječničko blago nekoga jezika koji je doista u upotrebi, ili je bilo u upotrebi, suzdržavajući se pritom od vrijednosnih kvalifikacija. Današnji rječnici teže iscrpnosti, vjerodostojnosti, točnosti, objektivnosti te nastoje pružiti korisniku informaciju do koje žele doći. Perskriptivni rječnici propisuju koje se riječi trebaju smatrati standardnima, ispravnima, pripustivima u birane književne tekstove ili govor javne komunikacije. Novi Kartografski rječnik je deskriptivan, on ništa ne propisuje. Međutim, zbog autorskoga pristupa koji omogućava izbor u pojedinim situacijama, on je implicitno i djelomično preskriptivan.

\subsection{Kratice}

U rječnik su uključene kratice koje su sastavni dio hrvatske stručne terminologije, npr. HTRS, UTM, DGU, ICA i mnoge druge. Tu se pojavila dvojba: treba li glavna natuknica u rječniku biti kratica ili puni naziv? Npr. HKD ili Hrvatsko kartografsko društvo?

To pitanje nije riješeno na jedinstveni način. Dogovorili smo se da glavna natuknica bude onaj naziv koji je učestaliji ili uobičajeniji. U konkretnom slučaju glavna natuknica je Hrvatsko kartografsko društvo, tj.

\section{društvo, Hrvatsko kartografsko}

strukovna udruga kartografa i drugih osoba koje pokazuju posebno zanimanje za kartografiju i srodna područja 


\section{Kratica: HKD}

Napomena: Osnovano je 2001. u Zagrebu. Organizira savjetovanja i objavljuje znanstveno-stručno-informativni časopis Kartografija i Geoinformacije.

En. Society, Croatian Cartographic (CCS)

Fr. Société Cartographique Croate

Nj. Gesellschaft, Kroatische kartographische

\section{HKD}

Vidi: Hrvatsko kartografsko društvo

Nasuprot tomu imamo:

\section{$D G U$}

kratica za Državna geodetska uprava što je hrvatska državna upravna organizacija koja obavlja poslove iz područja geodezije, kartografije, katastra i fotogrametrije te vodi brigu o uspostavi nacionalne infrastrukture prostornih podataka, informatizaciji katastra i geodetsko-prostornog sustava, državnoj službenoj kartografiji (1:5000, 1:25 000, 1:50 000, 1:100 000, 1:250 000), geodetskoj dokumentaciji, statističkim podatcima o katastru nekretnina, prostornim jedinicama i vodovima te geodetsko-katastarskim poslovima za državnu granicu

En. State Geodetic Administration (SGA)

Fr. Administration Géodésique d'État

$\mathrm{Nj}$. Landesvermessungsbehörde

\section{uprava, Državna geodetska}

Vidi: DGU

\subsection{Strani nazivi}

Neke strane riječi, kao što je npr. hardware, software ili web, ne doživljavamo kao strane riječi, premda izvorno nisu hrvatske. Udomaćile su se u hrvatskom jeziku višegodišnjom uporabom i smatramo da ih nije potrebno mijenjati na silu. Treba li umjesto naziva web pisati mreža? Ne ulazeći u širu raspravu, ovdje ćemo samo navesti da u području kartografije već imamo cijeli niz naziva u kojima se pojavljuje mreža, i to neovisno o informatičkoj pozadini, npr. geografska mreža, hidrografska mreža, kartografska mreža, trigonometrijska mreža itd. U Kartografskom rječniku riječ mreža 
pojavljuje se 251 put, od toga u nominativu 130 puta. Prema tome, ne vidimo potrebu davanja nazivu mreža još jedno novo značenje.

S obzirom na to da se engleska riječ software u hrvatskom jeziku piše softver, a hardware hardver, mogli bismo umjesto web pisati veb. No to ostavljamo budućnosti.

\subsection{Jednoznačnost i višeznačnost}

Sinonim nazivu u hrvatskom jeziku u Kartografskom rječniku označen je s također. Prednost se daje prvom navedenom nazivu. Ako u stranom jeziku postoje sinonimi, odvojeni su točkom sa zarezom (;).

Jedno od načela kojega se valja držati jest nedvosmislenost ili monosemija, odnosno treba izbjegavati sinonime. Međutim, postoje situacije kad na tome ne treba inzistirati. Primjer je uporaba naziva linija ili crta. To su dvije različite riječi koje općenito imaju isto ili vrlo slično značenje. Crta je očito u vezi s crtanjem, dio crteža. Ali ne mora biti. Tako npr. imamo graničnu crtu, obalnu crtu, crtu sredine itd. S druge strane imamo npr. geodetsku liniju ili geodetsku krivulju. Nitko ne kaže geodetska crta. U Kartografskom rječniku ostavili smo oba naziva:

crta

Također: linija

jednodimenzionalna osnovna geometrijska tvorevina

Napomena: Može biti ravna ili zakrivljena.

Vidi: linija kao kartografski znak

En. line

Fr. ligne

Nj. Linie

\section{linija}

(1) krivulja (2) niz povezanih koordinata točaka koje formiraju jednostavni linijski objekt

Napomena: Temeljna prostorna jedinica u vektorskome modelu podataka.

Upotrebljava se za prikazivanje objekata kao što su rijeke i ceste, ili za formiranje granice poligona. Katkad se naziva luk.

Vidi: crta; luk; model podataka, vektorski

En. line

Fr. ligne

Nj. Linie

Zanimljivo je da se na engleskom, francuskom i njemačkom jeziku crta i linija ne razlikuju. 
Višeznačnost jedne riječi, tj. polisemija, nastojala se izbjeći. Međutim, to nije uvijek bilo moguće. U takvim slučajevima u definiciji su različita značenja označena s (1) i (2), a ponekad i dalje. Npr. imamo:

\section{karta, suvremena}

(1) karta koja služi za objašnjavanje nekog suvremenog zbivanja (2) karta koja se neprekidno dorađuje, pa prikazuje suvremeno stanje

En. map, current; map, up-to-date

Fr. carte actuelle

Nj. Karte, aktuelle

\subsection{Nove definicije i novi nazivi}

U Kartografskom rječniku nastojali smo dati definicije koje su prihvaćene u struci. To su primjerice definicije kartografije i kartografa. Međutim, definicija karte je nova. Naime, definicija karte, prema Međunarodnome kartografskom društvu, prema kojoj je karta kodirana slika geografske stvarnosti koja prikazuje odabrane objekte ili svojstva, nastaje stvaralačkim autorskim izborom, a upotrebljava se onda kad su prostorni odnosi od prvorazredne važnosti, očito nije više prihvatliiva jer se na kartama ne prikazuje samo geografska stvarnost.

Prema novom Strateškom planu Međunarodnoga kartografskog društva (ICA 2019) »A map is an abstract visual representation of the geo-environment.« Ta definicija na prvi pogled lijepo zvuči, ali nas ne može zadovoljiti. Karta jest apstrakcija, ali nije nešto apstraktno. Karta je najčešće vizualni prikaz, ali ne uvijek, o čemu svjedoče karte za slijepe ili slabovidne osobe. I konačno, što je to geo-okoliš?

Naša nova definicija karte jest ona iz Kartografskoga rječnika:

\section{karta}

rezultat kartografskog preslikavanja

Vidi: preslikavanje, kartografsko

En. map

Fr. carte

Nj. Karte

Da bismo razumjeli tu definiciju moramo znati što je to kartografsko preslikavanje: 


\section{preslikavanje, kartografsko}

pridruživanje skupa prostornih podataka drugom skupu uz uvjet očuvanja prostornih odnosa i pojednostavljivanje detalja

Napomena: Rezultat kartografskog preslikavanja naziva se prikaz ili model ili karta, a pojednostavljivanje detalja je kartografska generalizacija.

En. mapping, cartographic

Fr. mise en correspondance cartographique

Nj. Abbildung, kartographische

Promjene kojima smo svjedoci svakoga dana u razvoju tehnologije općenito, pa i u kartografiji, nastojali smo zabilježiti u Kartografskom rječniku. Riječ je o novim nazivima i novim definicijama. Tako npr. imamo:

\section{kartografija, emocionalna}

dio kartografije koja se bavi trima glavnim aspektima odnosa između karata i emocija: emocije koje želimo kartografirati, emocije koje oblikuju proces kartografiranja i kartu, i emocije doživljene primjenom karata

En. cartography, emotional

Fr. cartographie émotionnelle

Nj. Kartographie, emotionale

\section{kartografiranje, masovno}

Također: kartografiranje, masovno podržano kartografiranje u kojem sudjeluje mnogo osoba

Vidi: kartografiranje; OpenStreetMap; kartografiranje, suradničko

En. mapping, crowdsourced; cartography, crowdsourced

\section{kartiranje, robotičko}

kartiranje mobilnim robotima opremljenima senzorima poput kamera, laserskih skenera, kompasa i GPS-a

Napomena: Pri izradi karte robot istovremeno rješava problem kartiranja i vlastitog lociranja u odnosu na kartu koju izrađuje. Robotičko kartiranje ima veliku primjenu u kartiranju zatvorenih prostora.

En. mapping, robotic

\subsection{Odstupanja od pravopisa}

Kartografski rječnik plod je suradnje dvojice profesora kartografije i jednoga lingvista. Za razliku od nesretnoga završetka Kartografsko-geoinformatičkoga rječnika, na 
kojem se radilo prije 12 godina, ovaj je rječnik izrađen uz harmonizaciju jezičnih načela i stručne terminologije.

U najvećoj je mjeri poštovan hrvatski pravopis, uz samo nekoliko manjih odstupanja. Npr. umjesto Karl Brandan Mollweide (1774. - 1825.) pišemo Karl Brandan Mollweide (1774-1825), jer je iz konteksta jasno da je riječ od godinama rođenja i smrti pa točke iza brojeva ne donose dodatnu obavijest, bez obzira na činjenicu da se redni brojevi razlikuju od glavnih upravo točkom na kraju. Točke su izostavljene gdje god njihovo pojavljivanje nije nužno.

Također, nismo inzistirali na razlikovanju kratica i pokrata po uzoru na Rječnik kratica (Babić, Žic Fuchs 2007).

\subsection{Poredak naziva u rječniku}

Svi su nazivi u rječniku poredani po abecedi. Kada se naziv sastoji od dviju ili više riječi, prva je uvijek imenica. Na primjer, tematska karta uvrštena je u rječnik kao karta, tematska. Zarez znači da je uobičajeni redoslijed riječi obrnut. Na isti način upisani su u rječnik i nazivi na stranim jezicima.

Redoslijed je mogao biti i drukčiji, tj. tako da najprije bude pridjev pa onda imenica. Svaki od navedenih redoslijeda ima neke prednosti i nedostatke. Odlučili smo se za prvoopisani redoslijed, prema kojem je na prvom mjestu imenica. Jedan od razloga je taj što su gotovo sve vrste karata na taj način u rječniku na jednom mjestu, a karta je svakako jedan od osnovnih pojmova i naziva u kartografiji.

\subsection{Planovi za budućnost}

Kartografski rječnik o kojem je riječ u ovom članku nastao je na klasičan način, što znači da su se autorima sigurno potkrale pogreške. No, budući da je to jedini rječnik takve vrste, on je i najbolji. Uočene pogreške popravit ćemo čim ih otkrijemo i uvrstiti u planirano izdanje rječnika na internetu, u planirano proširenje u kartografski leksikon te u englesku inačicu rječnika.

\section{Zaključak}

Kartografija, disciplina koja se bavi kartama, sastavni je dio geodezije, geografije, geologije, pomorstva, šumarstva, agronomije, povijesti, arhitekture, pedagogije i mnogih drugih područja koja se koriste kartama i geoinformacijama. Zahvaljujući razvoju novih tehnologija, kartografija je u posljednjih 40-ak godina doživjela velike promjene: papirnate se karte zamjenjuju multimedijskima i elektroničkima, a sve su 
češći i zahtjevi za trodimenzionalnim modelima krajolika zbog različitih analiza, simulacija i vizualizacija.

Novi Kartografski rječnik je strukovni rječnik koji sadržava 2500 naziva iz kartografije i njoj srodnih područja. Poredani abecedno, svi nazivi uza se imaju i sažetu definiciju, detaljnije objašnjenje daje uputa s vidi na srodne nazive, a u napomeni, ponekad i opsežnijoj, čitatelj može dobiti više informacija.

Definicije su na hrvatskom jeziku, a za većinu naziva dani su sinonimi na engleskom, francuskom i njemačkom jeziku. Kazala na kraju rječnika olakšavaju pronalaženje naziva na tim jezicima s uputama na odgovarajući naziv na hrvatskom jeziku.

U ovom članku opisana su iskustva koja su autori Kartografskog rječnika stekli dugogodišnjim radom na rječnicima. Zatim su objašnjeni problemi i dvojbe s kojima su se autori susreli pri radu na tom rječniku i opisani načini njihova rješavanja. Posebno je objašnjen pristup kraticama, stranim nazivima te jednoznačnosti i višeznačnosti naziva. Pojavila se i potreba za novim definicijama i novim nazivima. Objašnjena su mala odstupanja od pravopisa i prihvaćen redoslijed naziva u rječniku. $\mathrm{Na}$ kraju su spomenuti planovi za budućnost. 


\section{LITERATURA}

Babić, Stjepan, Žic Fuchs, Milena (2007). Rječnik kratica, Nakladni zavod Globus, Zagreb.

Borčić, Branko, Kreiziger, Ivan, Lovrić, Paško, Frančula, Nedjeljko (1977). Višejezični kartografski rječnik. Geodetski fakultet Sveučilišta u Zagrebu.

Frančula, Nedjeljko, Lapaine, Miljenko (2008). Geodetsko-geoinformatički rječnik, Državna geodetska uprava, Zagreb.

Frančula, Nedjeljko, Lapaine, Miljenko, Jazbec, Ivo-Pavao (2020). Kartografski rječnik, Hrvatsko kartografsko društvo, Naklada Dominović, Zagreb.

ICA (2019). Strategic Plan 2019-2027, General Assembly of the ICA, Tokyo.

Stefanović, Milutin (ur.) (1980). Višejezični geodetski rečnik, osmojezično izdanje. Savez geodetskih inženjera i geometara Jugoslavije, Beograd.

\section{ABOUT THE NEW CARTOGRAPHIC DICTIONARY}

\section{Miljenko Lapaine}

University of Zagreb, Faculty of Geodesy

miljenko.lapaine@geof.unizg.hr

Nedjeljko Frančula

University of Zagreb, Faculty of Geodesy

nfrancul@geof.hr

Ivo-Pavao Jazbec

Zagreb

ipjazbec@gmail.com

ABSTRACT: The Cartographic Dictionary was published by the Croatian Cartographic Society and Dominović Publishing last year. More than 40 years have passed since the publication of the first and only Multilingual Cartographic Dictionary in Croatia. In the dictionary, we have attempted to cover many changes which occurred in the world during this period. The present paper describes the circumstances and problems we encountered while preparing the dictionary.

Keywords: cartography; map; dictionary 